\title{
Applications of Nanomaterials for Heavy Metal Removal from Water and Soil: A Review
}

\author{
Guo Yu ${ }^{1,2}$, Xinshuai Wang ${ }^{1}$, Jie Liu ${ }^{1,2,3, *}$, Pingping Jiang ${ }^{1,2, *}$, Shaohong You ${ }^{1,2,3}$, Na Ding ${ }^{1}$, Qianjun Guo ${ }^{1}$ \\ and Fanyu Lin ${ }^{4}$
}

1 College of Environmental Science and Engineering, Guilin University of Technology, Guilin 541004, China; yuguo@glut.edu.cn (G.Y.); w_xinshuai@163.com (X.W.); youshaohong@glut.edu.cn (S.Y.); nading001@163.com (N.D.); tracy_gqj@163.com (Q.G.)

2 Guangxi Key Laboratory of Environmental Pollution Control Theory and Technology for Science and Education Combined with Science and Technology Innovation Base, Guilin University of Technology, Guilin 541004, China

3 Technical Innovation Center of Mine Geological Environmental Restoration Engineering in Southern Karst Area, Ministry of Natural Resources, Guilin 541004, China

4 Third Institute of Oceanography, Ministry of Natural Resources, Xiamen 200136, China; linfanyu@tio.org.cn

* Correspondence: liujie@glut.edu.cn (J.L.); jiangpp@glut.edu.cn (P.J.)

Citation: Yu, G.; Wang, X.; Liu, J.; Jiang, P.; You, S.; Ding, N.; Guo, Q.; Lin, F. Applications of Nanomaterials for Heavy Metal Removal from Water and Soil: A Review. Sustainability 2021, 13, 713. https://doi.org/ $10.3390 /$ su13020713

Received: 21 December 2020 Accepted: 8 January 2021 Published: 13 January 2021

Publisher's Note: MDPI stays neutral with regard to jurisdictional clai$\mathrm{ms}$ in published maps and institutional affiliations.

Copyright: (C) 2021 by the authors. Licensee MDPI, Basel, Switzerland. This article is an open access article distributed under the terms and conditions of the Creative Commons Attribution (CC BY) license (https:// creativecommons.org/licenses/by/ $4.0 /)$.

\begin{abstract}
Heavy metals are toxic and non-biodegradable environmental contaminants that seriously threaten human health. The remediation of heavy metal-contaminated water and soil is an urgent issue from both environmental and biological points of view. Recently, nanomaterials with excellent adsorption capacities, great chemical reactivity, active atomicity, and environmentally friendly performance have attracted widespread interest as potential adsorbents for heavy metal removal. This review first introduces the application of nanomaterials for removing heavy metal ions from the environment. Then, the environmental factors affecting the adsorption of nanomaterials, their toxicity, and environmental risks are discussed. Finally, the challenges and opportunities of applying nanomaterials in environmental remediation are discussed, which can provide perspectives for future in-depth studies and applications.
\end{abstract}

Keywords: nanomaterials; heavy metals; remediation; nanotoxicity

\section{Introduction}

As a result of extensive industrialization and urbanization over the past century, large amounts of heavy metal ions have been and continue to be discharged into the environment by human activities, such as electroplating, mining, chemical manufacturing, and the application of pesticides and fertilizers [1-3]. Heavy metal contamination in soil and water has become a major problem for many countries throughout the world $[4,5]$. Because of the non-biodegradable, persistent, and toxic nature of heavy metals, such as $\mathrm{Cr}(\mathrm{VI}), \mathrm{Cd}(\mathrm{II}), \mathrm{Pb}(\mathrm{II}), \mathrm{Cu}(\mathrm{II})$, and $\mathrm{Hg}(\mathrm{II})$, the ecological environment and human health are seriously threatened [6-8]. For example, the microbial biomass of soils contaminated with $\mathrm{Cd}, \mathrm{Pb}$, and $\mathrm{Cr}$ is seriously inhibited [9]. Moreover, even low concentrations of heavy metals present in the environment may cause serious environmental and health problems $[10,11]$. Therefore, in order to protect the ecological environment and public safety, it is imperative to remove these heavy metal ions from contaminated environments.

During the past few decades, numerous treatment methods have been developed to deal with heavy metal contamination, including physical methods, such as adsorption, coagulation, evaporation, and filtration; chemical methods, such as chemical precipitation, oxidation, ion exchange, and electrochemical processes; and biological methods, such as biodegradation and phytoremediation [12-15]. However, most of these treatment methods have significant drawbacks, such as high costs, complexity of operation, and secondary pollution [16-18]. For instance, despite the great removal efficiency of chemical 
precipitation, its installation cost is quite high [19]. Of all of the known methods, adsorption is widely used because of its low cost, high removal efficiency, strong practicality, high applicability, and good operability [20,21].

Absorbency is a key factor of the adsorption method. Therefore, it is crucial to select the most suitable adsorption material. A good adsorbent should have the advantages of a large specific surface, great sorption sites, diverse surface interactions, fast adsorption rates, and low costs [22-24]. Currently, the most commonly used adsorbents are biochar, activated carbon, carbon film, biopolymers, clay materials, and nanomaterials [25-27].

Nanomaterials are defined as materials that contain particles measuring between 1.0 and $100 \mathrm{~nm}$ in at least one dimension [28,29]. Since the emergence of nanomaterials in the 1970 s, an increasing number of researchers have focused on the application of nanomaterials in removing pollutants, such as heavy metals, organic pollutants, and pathogens, from contaminated surface waters, groundwater, sediments, and soil [27,30,31]. Nanomaterials are promising adsorbents and catalysts for the application of environmental remediation because of their great chemical reactivity, large adsorption surface, low temperature modification, and active atomicity [32,33]. The small size of nanoparticles makes it easier for the atoms at the surface to adsorb and have reactions with other atoms in order to achieve charge stabilization [34]. The large specific surface area can greatly improve the adsorption capacities of adsorbents $[29,35]$. In addition, because of the reduced size, nanomaterials have surfaces that are very reactive [36]. Not only can they efficiently adsorb pollutants, but they also have unique redox properties that are beneficial for the removal of redox-sensitive pollutants via degradation $[28,37]$. Studies on the removal of heavy metals using nanomaterials are of increasing importance and academic interest, as can be seen from the number of papers published every year, as shown in Figure 1. However, some of the commonly used nanomaterials do have limitations, including high costs, potential toxicity, difficulty in recycling, and an easy interaction with other media [16]. Even though nanomaterials have been widely studied in the field of heavy metal remediation, a comprehensive and systematic review of the application of nanomaterials for the removal of heavy metal ions is relatively lacking.

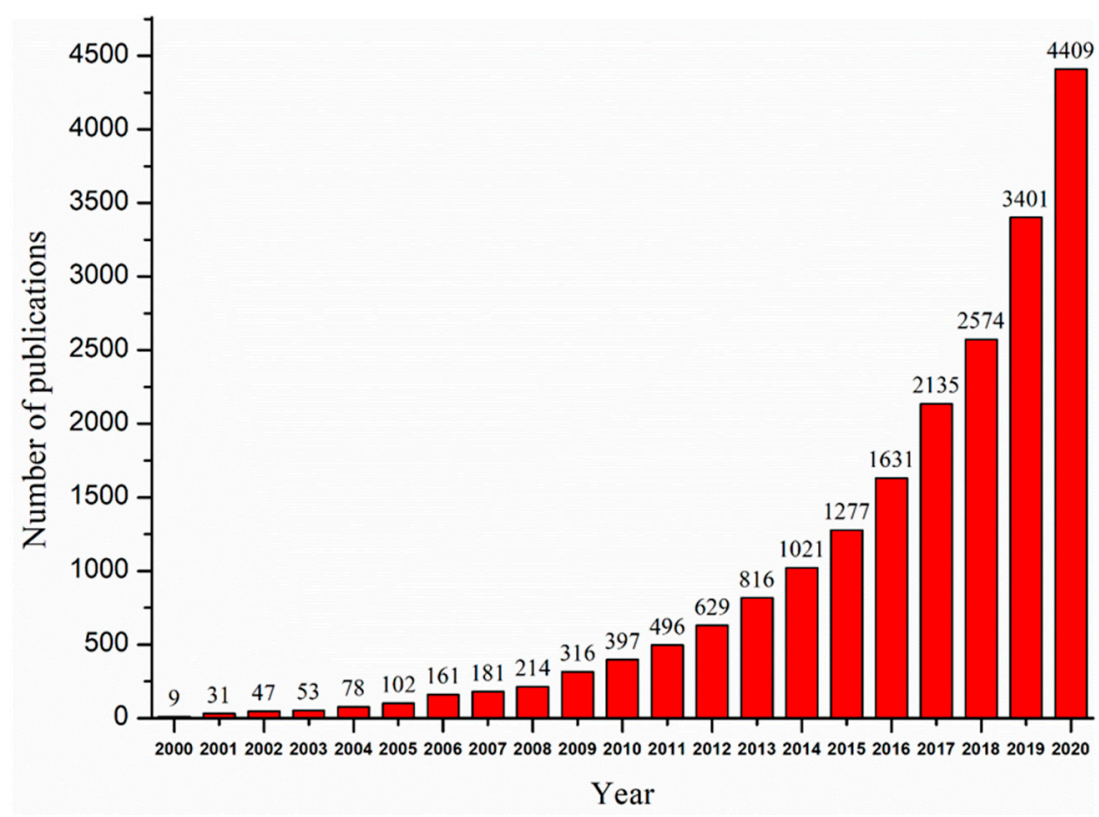

Figure 1. Trend of published papers on nanomaterials for removing heavy metals. Obtained from ScienceDirect. Search words (nanomaterials; heavy metal).

Therefore, this paper provides an overview of the application and related research of nanomaterials for removing heavy metal ions from contaminated soil and water and their performance in heavy metal remediation. Additionally, the environmental factors affecting 
the adsorption of nanomaterials, their toxicity, and environmental risks after application are discussed in detail. This review provides a reference for future large-scale applications of nanomaterials in remediation projects. Finally, the challenges and opportunities for the researchers who are working hard in this promising field of study are discussed.

\section{Types of Nanomaterials to Remove Heavy Metals}

Nanomaterials are classified into carbon-based nanomaterials and inorganic nanomaterials [38]. They have been widely applied in the field of environmental remediation. Among them, nano zero-valent iron (NZVI), carbon nanotubes (CNTs), and titanium dioxide nanoparticles $\left(\mathrm{TiO}_{2} \mathrm{NPs}\right.$ ) are the most frequently used and studied nanomaterials [39,40]. Table 1 summarizes the applications and the performance highlights of nanomaterials for removing heavy metals from water and soil environments.

Table 1. Applications of nanomaterials in removing heavy metals from the environment.

\begin{tabular}{|c|c|c|c|c|}
\hline $\begin{array}{c}\text { Types of } \\
\text { Nanomaterials }\end{array}$ & Environment & Target Heavy Metals & $\begin{array}{l}\text { Performance } \\
\text { Highlights }\end{array}$ & References \\
\hline NZVI-HCS & Water & $\begin{array}{c}\mathrm{Pb}(\mathrm{II}), \mathrm{Cu}(\mathrm{II}) \text {, and } \\
\mathrm{Zn}(\mathrm{II})\end{array}$ & $\begin{array}{l}\text { The maximum } \\
\text { adsorption capacities } \\
\text { were } 195.1,161.9 \text {, and } \\
109.7 \mathrm{mg} \cdot \mathrm{g}^{-1} \text { for } \mathrm{Pb}(\mathrm{II}) \text {, } \\
\mathrm{Cu}(\mathrm{II}) \text {, and } \mathrm{Zn}(\mathrm{II}) \text {, } \\
\text { respectively }\end{array}$ & [41] \\
\hline NZVI & Sediment & $\mathrm{Cd}(\mathrm{II})$ & $\begin{array}{l}\text { The maximum } \\
\text { adsorption capacity of } \\
\text { for Cd(II) was } \\
769.2 \mathrm{mg} \mathrm{g}^{-1} \text { at } 297 \mathrm{~K}\end{array}$ & [42] \\
\hline BC-NZVI & Water & $\mathrm{Cr}(\mathrm{VI})$ & $\begin{array}{l}\text { The performance of } \\
\text { BC-NZVI was pH } \\
\text { dependent, with a } \\
\text { maximum } \mathrm{Cr}(\mathrm{VI}) \\
\text { removal efficiency of } \\
98.71 \% \text { at } \mathrm{pH} 2\end{array}$ & [43] \\
\hline BC-NZVI & Soil & $\mathrm{Cr}(\mathrm{VI})$ & $\begin{array}{l}\text { The immobilization } \\
\text { efficiency of } \mathrm{Cr}(\mathrm{VI}) \text { and } \\
\text { total } \mathrm{Cr} \text { reached } 100 \% \\
\text { and } 92.9 \% \text {, respectively, } \\
\text { when } 8 \mathrm{~g} \mathrm{~kg}^{-1} \text { of } \\
\text { BC-NZVI was applied } \\
\text { for } 15 \mathrm{~d}\end{array}$ & {$[44]$} \\
\hline NZVI & Water & $\mathrm{Pb}(\mathrm{II})$ & $\begin{array}{l}\text { The maximum } \\
\text { adsorption capacity of } \\
\text { NZVI was } \\
807.23 \mathrm{mg} \cdot \mathrm{g}^{-1} \text { at } \mathrm{pH} 6\end{array}$ & {$[45]$} \\
\hline OA-NZVI & Soil & $\begin{array}{c}\mathrm{Cd}(\mathrm{II}), \mathrm{Pb}(\mathrm{II}), \text { and } \\
\mathrm{Zn}(\mathrm{II})\end{array}$ & $\begin{array}{l}\text { The highest } \mathrm{Cd}, \mathrm{Pb} \text {, } \\
\text { and } \mathrm{Zn} \text { removal } \\
\text { efficiencies were } \\
46.66 \%, 48.88 \% \text { and } \\
47.01 \% \text {, respectively, for } \\
\text { farmland soil at the } \\
\mathrm{NZVI} \text { concentration of } \\
0.4 \mathrm{~g} \mathrm{~L}^{-1}\end{array}$ & [46] \\
\hline MWCNTs & Water & $\mathrm{Zn}(\mathrm{II})$ & $\begin{array}{l}\text { The maximum } \\
\text { adsorption efficiency } \\
\text { was } 96.27 \% \text { at } \mathrm{pH} 5 \text { for } \\
6 \mathrm{~h}\end{array}$ & [47] \\
\hline
\end{tabular}


Table 1. Cont.

\begin{tabular}{|c|c|c|c|c|}
\hline $\begin{array}{c}\text { Types of } \\
\text { Nanomaterials }\end{array}$ & Environment & Target Heavy Metals & $\begin{array}{c}\text { Performance } \\
\text { Highlights }\end{array}$ & References \\
\hline MWCNTs-COOH & Water & $\mathrm{Hg}(\mathrm{II})$ and $\mathrm{As}(\mathrm{III})$ & $\begin{array}{l}\text { The maximum removal } \\
\text { efficiencies for } \mathrm{Hg}(\mathrm{II}) \\
\text { and } \mathrm{As}(\mathrm{III}) \text { were } 80.5 \% \\
\text { and } 72.4 \% \text { at the } \\
\text { adsorbent dose of } \\
20 \mathrm{mg} \mathrm{L}^{-1} \text { and pH } \\
7.6-7.9 \text {, respectively }\end{array}$ & [48] \\
\hline CNTs & Water & $\mathrm{Zn}(\mathrm{II})$ & $\begin{array}{l}\text { The maximum } \\
\text { adsorption capacities of } \\
\mathrm{Zn}(\mathrm{II}) \text { were } 43.66 \text { and } \\
32.68 \mathrm{mg} \mathrm{g}^{-1} \text { by } \\
\text { SWCNTs and } \\
\text { MWCNTs, respectively }\end{array}$ & [49] \\
\hline $\mathrm{TiO}_{2}-\mathrm{NCH}$ & Water & $\mathrm{Cd}(\mathrm{II})$ and $\mathrm{Cu}(\mathrm{II})$ & $\begin{array}{l}\text { The maximum } \\
\text { adsorption efficiency of } \\
\mathrm{Cu}(\mathrm{II}) \text { and } \mathrm{Cd}(\mathrm{II}) \text { from } \\
\text { wastewater samples } \\
\text { were } 88.01 \% \text { and } \\
70.67 \% \text {, respectively }\end{array}$ & {$[50]$} \\
\hline $\begin{array}{l}\text { Mesoporous } \\
\text { carbonated } \\
\mathrm{TiO}_{2} \mathrm{NPs}\end{array}$ & Water & $\mathrm{Sr}(\mathrm{II})$ & $\begin{array}{l}\text { The maximum } \\
\text { adsorption capacity of } \\
\mathrm{Sr}(\mathrm{II}) 204.4 \mathrm{mg} \mathrm{g}^{-1} \text { at } \\
\text { the natural } \mathrm{pH} \text { by } \\
4 \mathrm{C}-\mathrm{TiO}_{2}\end{array}$ & [51] \\
\hline $\mathrm{TiO}_{2} \mathrm{NPs}$ & Soil & $\mathrm{Cd}(\mathrm{II})$ & $\begin{array}{l}\text { The greatest Cd } \\
\text { accumulation capacity } \\
\text { of Trifolium repens } \\
\text { reached } 1235 \mu \text { pot }^{-1} \\
\text { with PGPR + } \\
500 \mathrm{mg} \mathrm{kg}^{-1} \mathrm{TiO}_{2} \mathrm{NPs} \\
\text { treatment }\end{array}$ & [52] \\
\hline
\end{tabular}

\subsection{Nano Zero-Valent Iron (NZVI)}

NZVI is the most widely studied and applied nanomaterial in environmental remediation and has been proven to be an effective adsorbent, reductant, and catalyst for a variety of contaminants, such as heavy metal ions, halogenated organic compounds, organic dyes, and pharmaceuticals [46-48]. NZVI has a typical core shell structure generated during the synthesis process that contains a shell of $\mathrm{Fe}(\mathrm{II}), \mathrm{Fe}(\mathrm{III})$, and zero-valent iron [53]. As a result of the unique structure, NZVI has the abilities of reduction, surface sorption, stabilization, and precipitation of various contaminants [54-56]. Several studies have reported that NZVI exhibited excellent performance for removing heavy metal(loid) ions from contaminated environments [41-44]. For instance, Yang et al. [41] applied a corn stalk-derived, biochar-supported NZVI for the removal of heavy metal ions from water. The results showed that the equilibrium adsorption capacities reached 195.1, 161.9, and $109.7 \mathrm{mg} \cdot \mathrm{g}^{-1}$ for $\mathrm{Pb}(\mathrm{II}), \mathrm{Cu}(\mathrm{II})$, and $\mathrm{Zn}$ (II) after $6 \mathrm{~h}$, respectively. Boparai et al. [42] reported that NZVI could be applied as an efficient adsorbent to remove cadmium from contaminated water. The maximum adsorption capacity of NZVI for Cd(II) was $769.2 \mathrm{mg} \mathrm{g}^{-1}$, which was achieved at a temperature of $297 \mathrm{~K}$. Su et al. [44] found that the immobilization efficiency of $\mathrm{Cr}(\mathrm{VI})$ reached $100 \%$ when $8 \mathrm{~g} \mathrm{~kg}^{-1}$ of biochar-supported NZVI was applied in hexavalent chromium-contaminated soil for 15 days. Acid mine water was treated using NZVI, and this resulted in a significant decrease in the concentrations of microcontaminants, such as $\mathrm{U}, \mathrm{V}, \mathrm{As}, \mathrm{Cr}, \mathrm{Cu}, \mathrm{Cd}, \mathrm{Ni}$, and $\mathrm{Zn} \mathrm{[57].} \mathrm{Huang} \mathrm{et} \mathrm{al.} \mathrm{[58]} \mathrm{investigated} \mathrm{the} \mathrm{effects} \mathrm{of}$ 
different dosages of NZVI on plant growth and the $\mathrm{Pb}$ accumulation of Lolium perenne. The $\mathrm{Pb}$ accumulation and plant biomass were significantly enhanced when the NZVI and $\mathrm{Pb}$ accumulation in $L$. perenne reached a maximum of $1175.40 \mu \mathrm{g}$ per pot with the treatment of $100 \mathrm{mg} \mathrm{kg}^{-1}$ NZVI. Vítková et al. [59] reported that NZVI application significantly stabilized the As and $\mathrm{Zn}$ in As-rich and Zn-rich soils by the formation of Fe (hydr)oxides. Han et al. [60] investigated the removal efficiency of permeable reactive barriers (PRBs) filled with zero-valent iron (ZVI) and zero-valent aluminum (ZVAl) as a reactive medium and discussed the reaction mechanism of $\mathrm{Cr}(\mathrm{VI}), \mathrm{Cd}(\mathrm{II}), \mathrm{Ni}(\mathrm{II}), \mathrm{Cu}(\mathrm{II})$, and $\mathrm{Zn}$ (II) with ZVI/ZVAl. The main possible mechanisms were adsorption, formation of metal hydroxide precipitates, and reduction, which are shown in Figure 2.

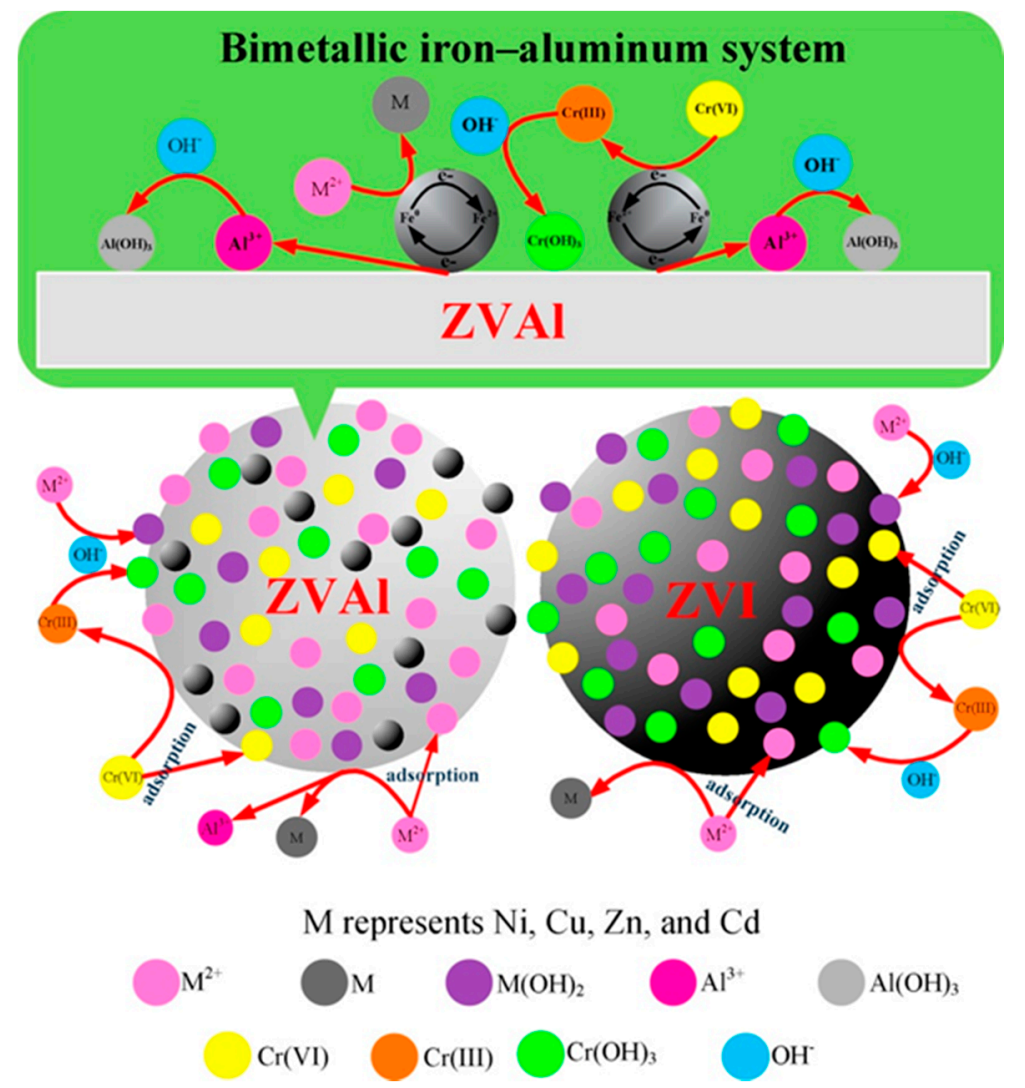

Figure 2. Removal mechanisms of five heavy metal ions by zero-valent iron/zero-valent aluminum (ZVI/ZVAl). Reproduced with permission from ref 60 published by Elsevier, 2016.

\subsection{Carbon Nanotubes (CNTs)}

CNTs, which were first discovered in 1991, have a unique chemical structure that consists of a graphitic sheet rolled up in a cylindrical shape [61,62]. CNTs are very strong materials that are over 100 times more resistant and six times lighter than steel [63]. Depending on the number of cylindrical shells, CNTs are classified into two categories: single wall CNTs (SWCNTs) and multi-wall CNTs (MWCNTs). Because of their extraordinary characteristics, such as a large specific surface area, unique morphology, and high reactivity, CNTs are considered to be an excellent nanomaterial for the removal of various organic and inorganic pollutants $[64,65]$. CNTs can be produced via methods such as chemical vapor deposition, laser ablation, and arc discharge. The adsorption capacity of CNTs is greatly affected by the methods by which they are synthesized with different reactants and catalysts [66]. For instance, Mubarak et al. [67] studied the effect of microwave-assisted MWCNTs on the removal of $\mathrm{Zn}$ (II) from wastewater. The results showed that the highest removal rate $(99.9 \%)$ was achieved at $\mathrm{pH} 10$ and a CNTs dosage of $0.05 \mathrm{~g}$. Sun et al. [68] found that the removal efficiency of Cd(II) by CNTs increased at pH 3. Osman et al. [69] 
reported that CNTs synthesized from potato peel-waste material removed up to $84 \%$ of $\mathrm{Pb}$ (II) within $1 \mathrm{~h}$ of the CNTs' application. Yaghmaeian et al. [70] used MWCNTs as a sorbent to remove $\mathrm{Hg}$ (II) from wastewater. The results showed that an adsorption capacity of $25.64 \mathrm{mg} \mathrm{g}^{-1}$ and a removal rate of greater than $85 \%$ were achieved when operated at $25{ }^{\circ} \mathrm{C}, \mathrm{pH} 7$, with a contact time of $120 \mathrm{~min}$. Sobhanardakani et al. [71] prepared oxidized MWCNTs and used it as an adsorbent for the removal of $\mathrm{Cu}$ (II) from an aqueous solution. The maximum removal rate for $\mathrm{Cu}(\mathrm{II})$ was $99.5 \%$ at the optimum temperature $\left(25^{\circ} \mathrm{C}\right)$ and the most suitable $\mathrm{pH}$ value (6.0). There may be various pathways for heavy metal removal by CNTs, including adsorption, electrostatic interaction, reduction, and ion exchange, depending on the novel properties provided by functionalization and the heavy metal ions (Figure 3).

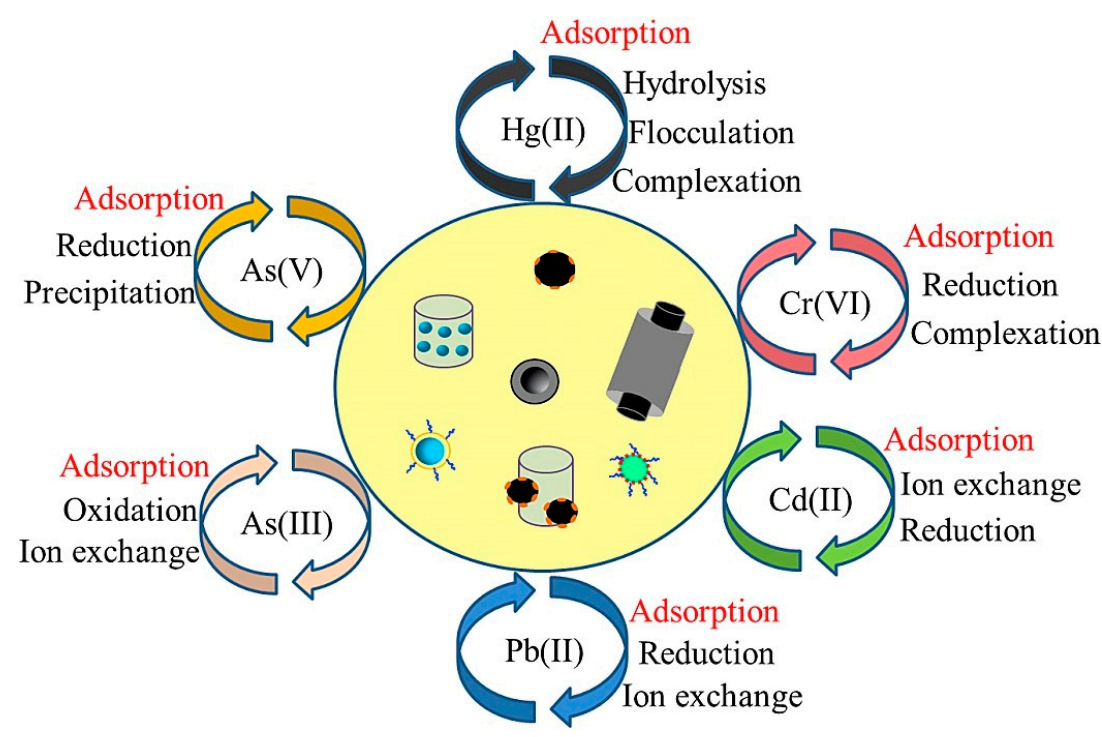

Figure 3. The mechanisms of removing heavy metal from an aqueous environment by carbon nanotubes (CNTs). Reproduced with permission from ref [72] published by Elsevier, 2018.

\subsection{Titanium Dioxide Nanoparticles ( $\left.\mathrm{TiO}_{2} \mathrm{NPS}_{\mathrm{S}}\right)$}

Among the nanomaterials used for environmental remediation, $\mathrm{TiO}_{2} \mathrm{NPs}$ have been extensively studied [73]. $\mathrm{TiO}_{2}$ NPs show good abilities for photocatalysis, high reactivity, and chemical stability, and they have been successfully applied for modifying the mobility and toxicity of heavy metals in water, soil, and sediment [74,75]. In addition, another advantage of $\mathrm{TiO}_{2}$ NPs is their ease of synthesis. Goutam et al. [76] synthesized $\mathrm{TiO}_{2}$ NPs using a leaf extract and used it to treat tannery wastewater. The results showed that $76.48 \%$ of the $\mathrm{Cr}$ was removed from the wastewater using green-synthesized $\mathrm{TiO}_{2} \mathrm{NPs}$. Mahmoud et al. [77] reported that the microwave-synthesized $\mathrm{TiO}_{2} \mathrm{NPs}_{\text {bonded with }}$ the chitosan nanolayer and removed $88.01 \%$ of the $\mathrm{Cu}$ (II) and $70.67 \%$ of the Cd (II) from wastewater when the $\mathrm{pH}$ value was 7.0. Gebru et al. [78] synthesized cellulose acetate (CA) $/ \mathrm{TiO}_{2}$ NPs using a new electrospinning technique and tested its adsorption capacity for removing $\mathrm{Pb}(\mathrm{II})$ and $\mathrm{Cu}(\mathrm{II})$ ions from water. The $\mathrm{CA} / \mathrm{TiO}_{2}$ adsorbent removed $99.7 \%$ and $98.9 \%$ of $\mathrm{Pb}(\mathrm{II})$ and $\mathrm{Cu}(\mathrm{II})$ ions under the most optimized conditions. Fan et al. [79] reported that the concentrations of exchangeable, carbonate, and iron-manganese oxide of As and $\mathrm{Pb}$ in the sediments decreased with an increasing amount of $\mathrm{TiO}_{2} \mathrm{NPs}_{\text {. Singh and }}$ Lee [80] investigated the effect of $\mathrm{TiO}_{2} \mathrm{NPs}$ on $\mathrm{Cd}$ phytoremediation in Glycine max. The results showed that the $\mathrm{Cd}$ accumulation in the aerial portions of the plants increased by approximately 2.6 times when $300 \mathrm{mg} \mathrm{kg}^{-1} \mathrm{TiO}_{2}$ NPs were added to the soil. Zhao et al. [81] proposed the possible removal mechanisms of $\mathrm{Cr}(\mathrm{VI})$ by reduced graphene oxide decorated with $\mathrm{TiO}_{2} \mathrm{NPs}\left(\mathrm{TiO}_{2}-\mathrm{RGO}\right)$, which is shown in Figure 4. It was speculated that the negatively charged $\mathrm{Cr}(\mathrm{VI})$ was bound to the surface of $\mathrm{TiO}_{2}-\mathrm{RGO}$, which had a positive 
charge and was reduced to $\mathrm{Cr}$ (III). Then, the $\mathrm{Cr}$ (III) species was released into the solution due to electrostatic repulsion with the surface of $\mathrm{TiO}_{2}-\mathrm{RGO}$.

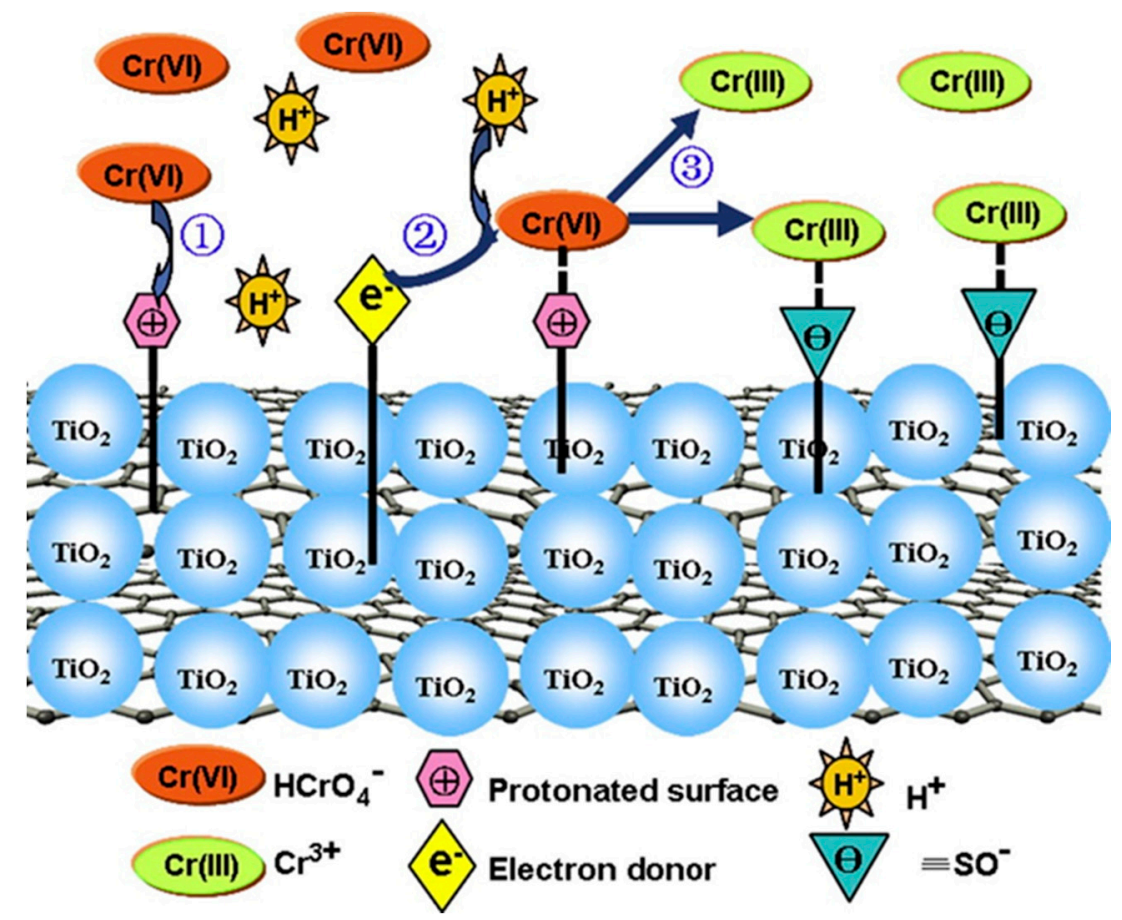

Figure 4. The possible mechanism of $\mathrm{Cr}(\mathrm{VI})$ reduction by $\mathrm{TiO}_{2}-\mathrm{RGO}$. Reproduced with permission from ref 81 published by Elsevier, 2013.

\section{Environmental Factors Affecting the Performance of Nanomaterials}

\subsection{The Effect of $p H$}

The solution $\mathrm{pH}$ is an important parameter in the reactions of nanomaterials with heavy metal ions [25]. The solution $\mathrm{pH}$ value affects the surface charge of the nanomaterial and thus affects its adsorption ability. In addition, the $\mathrm{pH}$ determines the bioavailability and existent forms of heavy metal ions [82]. At a lower $\mathrm{pH}$, more protons react with nanomaterials, such as NZVI, and the conversion of $\mathrm{H}^{+}$to $\mathrm{H}_{2}$ can result in more reactive atomic hydrogen and a faster reduction rate. The surface coordination, electrostatic sorption, and precipitation become stronger under neutral $\mathrm{pH}$ conditions, which leads to a higher removal rate [83]. For example, Zhao et al. [84] reported that the adsorption ability of NZVI decreased significantly under strong alkaline or acidic conditions. The NZVI corrosion was affected by the $\mathrm{pH}$, and thus affected its reactive lifetime. Liu et al. [85] investigated the effects of the $\mathrm{pH}$ on the removal efficiency of $\mathrm{Hg}(\mathrm{II})$ and $\mathrm{Cr}(\mathrm{VI})$ by a pumice-supported NZVI from an aqueous solution. The results showed that when the $\mathrm{pH}$ increased from 3.1 to 8.1 , the $\mathrm{Hg}$ (II) removal rates increased, while the $\mathrm{Cr}(\mathrm{VI})$ removal rates decreased. Wu et al. [86] found that the $\mathrm{Cr}(\mathrm{VI})$ removal rate of FeS nanoparticles stabilized by sodium alginate increased from $92.51 \%$ to $99.65 \%$ when the $\mathrm{pH}$ was increased from 4.0 to 6.0 , while the $\mathrm{Cr}(\mathrm{VI})$ removal rate decreased to 65.37 when the $\mathrm{pH}$ was 10.0. $\mathrm{Xu}$ and Zhao [87] investigated the effect of the $\mathrm{pH}$ on the $\mathrm{Cr}(\mathrm{VI})$ immobilization in contaminated soil using carboxymethyl cellulose-stabilized NZVI. The results showed that the $\mathrm{Cr}(\mathrm{VI})$ leached from the soil reduced from around $30 \%$ to $20 \%$, with the soil $\mathrm{pH}$ decreasing from 9.0 to 5.0.

\subsection{The Effect of the Contact Time}

Generally, the contact time between nanoparticles and heavy metal ions can significantly affect the removal rates during the adsorption and redox process [88]. Several studies have investigated the effects of contact time by applying models such as the pseudo-firstorder, the pseudo-second-order, the Zeldowitsch, and the Lagergren kinetic models [89]. 
Typically, the adsorption rate of heavy metal ions onto nanomaterials quickly reached the highest point in the beginning phase and then slowed down with time until the sorption equilibrium was reached. Specifically, Gong et al. [90] found that the $\mathrm{Hg}$ (II) removal rate by the sodium carboxymethyl cellulose-stabilized FeS nanoparticles reached the highest point within 30 minutes and slowly decreased until equilibrium was achieved at approximately $6 \mathrm{~h}$. It was reported by $\mathrm{Lv}$ et al. [91] that $\mathrm{Cr}(\mathrm{VI})$ was removed rapidly by $\mathrm{NZVI}-\mathrm{Fe}_{3} \mathrm{O}_{4}$ nanocomposites within $2 \mathrm{~h}$ and then slowed down until equilibrium. The kinetics model was described well by the pseudo-second-order model. Cao et al. [46] investigated the removal efficiency of $\mathrm{Cd}(\mathrm{II}), \mathrm{Pb}(\mathrm{II})$, and $\mathrm{Zn}$ (II) from mine- and farmland-contaminated soils using the soil-washing method with the application of NZVI combined with lowmolecular-weight organic acids. The results showed that the removal efficiency of heavy metals increased rapidly in the first $2 \mathrm{~h}$ and then slowed down until equilibrium. The initial process of $2 \mathrm{~h}$ was described by the pseudo-first-order model, and the whole process of $12 \mathrm{~h}$ was described by the pseudo-second-order model.

\subsection{The Effect of the Adsorbent Dosage}

The dosage of the nanomaterials used is another key factor that affects the removal capacities of heavy metal ions. Many publications have selected the optimum dosage of adsorbents that can achieve the desired removal efficiency, which is useful for the costeffective application of nanomaterials. Arshadi et al. [92] reported that the $\mathrm{Pb}$ (II) removal rate by immobilized NZVI on the sineguelas waste biomaterial increased from $15.6 \%$ to $89 \%$ when the adsorbent dosage increased from 0.05 to $0.15 \mathrm{~g}$. However, a higher adsorbent dosage did not result in a significant increase in the removal rate of $89 \%$. Fu et al. [32] investigated the removal efficiency of $\mathrm{Cr}(\mathrm{VI})$ and $\mathrm{Pb}(\mathrm{II})$ from groundwater by sepiolitesupported NZVI. The results showed that when the adsorbent dosage was increased from 0.05 to $3.2 \mathrm{~g} \mathrm{~L}^{-1}$, the $\mathrm{Cr}(\mathrm{VI})$ removal rate was raised from $45.1 \%$ to $99.2 \%$, and the $\mathrm{Pb}$ (II) removal rate was raised from $56.2 \%$ to $99.9 \%$. However, a dosage of $1.6 \mathrm{~g} \mathrm{~L}^{-1}$ sepiolitesupported NZVI was selected as the optimal dosage because the pseudofirst-order rate constants of $\mathrm{Cr}(\mathrm{VI})$ and $\mathrm{Pb}$ (II) did not increase significantly after the adsorbent dosage of $1.6 \mathrm{~g} \mathrm{~L}^{-1}$. Zand et al. [52] investigated the phytoremediation of the Cd contaminated soil with the application of different doses of $\mathrm{TiO}_{2} \mathrm{NPs}$. The results showed that the $\mathrm{Cd}$ uptake by Trifolium repens was significantly enhanced when the application dosage of $\mathrm{TiO}_{2} \mathrm{NPs}$ was increased from 0 to $500 \mathrm{mg} \mathrm{kg}^{-1}$. The application of $1000 \mathrm{mg} \mathrm{kg}^{-1} \mathrm{TiO}_{2} \mathrm{NPs}$ resulted in a significant reduction of plant biomass due to toxic effects.

\subsection{The Effect of Temperature}

The temperature determines the energy of reaction activity and thus plays key roles in the adsorption process. The increase or decrease in temperature can alter the equilibrium adsorption capacity of nanomaterials. Furthermore, the higher temperature can reduce the distance between nanoparticles and increase the redox reaction rate. Dubey et al. [93] studied the removal efficiency of $\mathrm{Hg}$ (II) by chitosan-alginate nanoparticles when the temperature ranged from 10 to $40^{\circ} \mathrm{C}$. The results showed that the removal efficiency increased with the increasing temperature until $30^{\circ} \mathrm{C}$ and then started to decrease. Similar results were also reported elsewhere [94]. Nassar [95] reported that the $\mathrm{Pb}(\mathrm{II})$ adsorption by $\mathrm{Fe}_{3} \mathrm{O}_{4}$ nanomaterials increased with the increase of temperature from 298 to $328 \mathrm{~K}$, which indicated that the adsorption process was endothermic. Liu et al. [96] investigated the immobilization efficiency of Re(VII) using starch-stabilized NZVI in soil and groundwater. The results showed that the immobilization efficiency of $\operatorname{Re}(\mathrm{VII})$ increased with the increasing temperature from 15 to $45^{\circ} \mathrm{C}$. The results can be explained by the classical Arrhenius equation.

\section{Environmental Impacts of Nanomaterials}

Nanomaterials have provided a wide range of applications for reducing/immobilizing metal(loid)s in contaminated water and soil $[96,97]$. However, the massive use of nano- 
materials will inevitably result in their elevated concentrations in the environment, which may affect ecological security and human health [98-104]. The toxicity of nanomaterials and their ability to change the bioavailability of toxic contaminants such as heavy metals should not be neglected [105-107]. It is of great importance to investigate the environmental impacts of nanomaterials due to their increasing use in the remediation of contaminated water and soil. Lu et al. [106] reported that the toxicity of Cd(II) for Artemia salina, a model marine zooplankton, increased by $12.2 \%$ when $5 \mathrm{mg} \mathrm{L}^{-1}$ of $\mathrm{TiO}_{2} \mathrm{NPs}_{\text {was }}$ added.

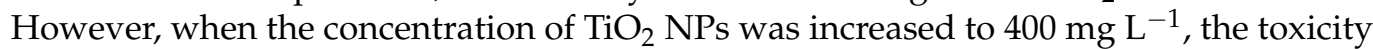
of $\mathrm{Cd}(\mathrm{II})$ was reduced to $57.1 \%$, which indicated a concentration-dependent toxicity of nanomaterials. Deng et al. [107] investigated the physiological and biochemical responses of Phaeodactylum tricornutum to $\mathrm{TiO}_{2}$ NPs. The results showed that the growth inhibition rate of P. tricornutum increased from $5.46 \%$ to $27.31 \%$ when the dosage of $\mathrm{TiO}_{2} \mathrm{NPs}_{\text {in- }}$ creased from 2.5 to $40 \mathrm{mg} \mathrm{L}^{-1}$ at an exposure of $96 \mathrm{~h}$. Lam et al. [108] found that the mice treated with high dosages of single-wall carbon nanotubes revealed peribronchial inflammation, while the mice treated with carbon black were normal. Lindberg et al. [109] revealed that CNTs induced a dose-dependent increase in DNA damage assessed by a single cell gel electrophoresis assay and a micronucleus assay in human bronchial epithelial BEAS 2B cells. A study showed that a dosage of NZVI up to $10 \mathrm{mg} \mathrm{L}^{-1}$ resulted in a doubling of the decrease in fertilization success of marine organisms including mussels, sea squirts, and urchins [110]. El-Temsah and Joner [111] reported that NZVI had toxicity effects on soil microorganisms (ostracods and collembola), especially after a 7-d incubation. However, the toxicity effect was observed to be alleviated with the increase in incubation time. Fajardo et al. [112] investigated the impacts of NZVI on soil microbial structures and functionality. The results showed that the application of $10 \mathrm{mg} \mathrm{mL}^{-1} \mathrm{NZVI} \mathrm{had} \mathrm{no}$ significant effect on the cellular viability and biological activity of the soil microorganisms. The FISH assays showed that NZVI promoted the dominance of some microbial groups and thus changed the soil microbial structure. As discussed in Section 3.3, the dosage of nanomaterials is a key factor for removing heavy metals from the environment. However, the toxicity of nanomaterials has also been shown to be dosage dependent [113]. In conclusion, previous studies showed that nanomaterials had toxicity effects on microorganisms, aquatic organisms, and plants [106-113]. The feasibility of applying nanomaterials in the remediation of contaminated water and soil should be questioned. However, it is worth noticing that the toxicity of nanomaterials is affected by the tested organism species, the dosage of nanomaterials, and the environmental factors. Therefore, it is difficult to conduct a comprehensive and in-depth analysis of the toxicity effects of nanomaterials. Moreover, the selection of a suitable modification method, synthesis method, and the dosage of nanomaterials can minimize the adverse effect on the environment.

\section{Conclusions and Future Perspectives}

Nanomaterials are revolutionary materials with properties that include nanoscale size, large specific surface area, and great reactivity. According to the current knowledge, nanomaterials have substantial potential for remediating heavy metal-contaminated water and soil. In this review, the applications, environmental factors, toxicity, and future perspectives of nanomaterials on heavy metal remediation were discussed, as shown in Figure 5. Their applications in the field of environmental pollution control, especially in heavy metal remediation will certainly continue to be studied. Despite the many advantages of nanomaterials, there are still several challenges in their application for heavy metal remediation that require attention in future studies, including: (1) the toxicity of nanomaterials on the plants, animals, and the microbial community; (2) the management and regeneration of nanomaterials; (3) the recovery of heavy metal ions from saturated nanomaterials; (4) the methods to decrease the aging of nanomaterials; (5) the combined application of nanomaterials with other treatments such as phytoremediation; (6) the synergistic or antagonistic effects of nanomaterials and microbial activities; and (7) the long-term stability of heavy metal remediation by nanomaterials, especially in field studies. 


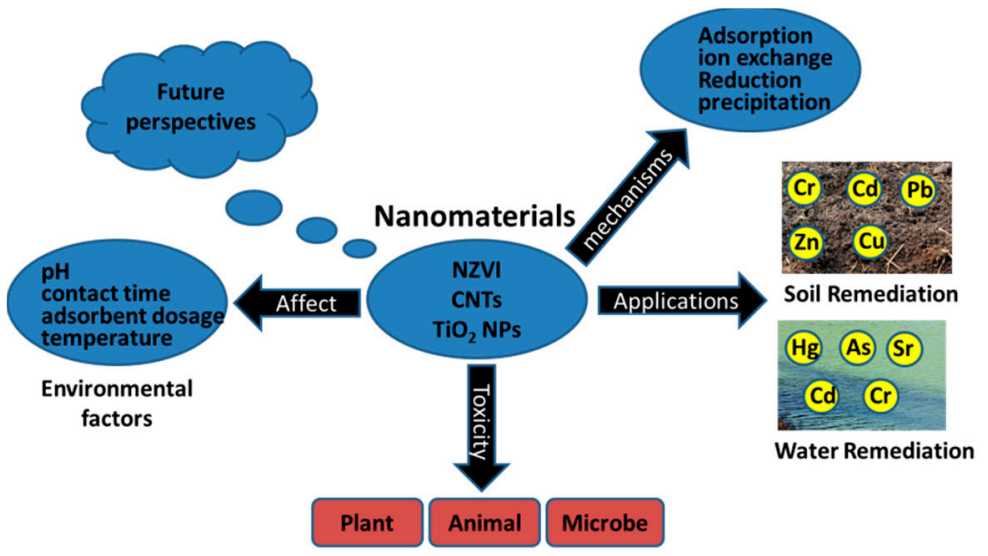

Figure 5. Applications of nanomaterials for heavy metal removal from water and soil.

Author Contributions: Conceptualization, G.Y. and P.J.; methodology, X.W.; software, N.D.; validation, S.Y., Q.G. and F.L.; formal analysis, G.Y.; investigation, P.J.; resources, G.Y.; data curation, X.W.; writing — original draft preparation, G.Y.; writing—review and editing, J.L.; visualization, P.J.; supervision, J.L.; project administration, J.L.; funding acquisition, J.L. All authors have read and agreed to the published version of the manuscript.

Funding: This research was sponsored by the National Science Foundation of China (Grant No. 51868010, 41867022), the Special Funds of Guangxi Distinguished Experts, the Program for High Level Innovation Team and Outstanding Scholar of Universities in Guangxi (Grant No. GuiCaijiaoHan [2018]319), the Guangxi Science and Technology Project (2018AD16013-04), and the Guilin Science and Technology Project (Grant No. 20190219-3).

Institutional Review Board Statement: Ethical review and approval were waived for this study.

Informed Consent Statement: Not applicable.

Data Availability Statement: All data, models, and code generated or used during the study appear in the submitted article.

Acknowledgments: The authors wish to thank the anonymous reviewers and the editor for their comments and suggestions.

Conflicts of Interest: The authors declare no conflict of interest.

\section{References}

1. Ok, Y.S.; Oh, S.E.; Ahmad, M.; Hyun, S.; Kim, K.R.; Moon, D.H.; Lee, S.S.; Lim, K.J.; Jeon, W.T.; Yang, J.E. Effect of natural and calcined oyster shells on $\mathrm{Cd}$ and $\mathrm{Pb}$ immobilization in contaminated soils. Environ. Earth Sci. 2010, 61, 1301-1308. [CrossRef]

2. Li, J.; Wang, X.; Zhao, G.; Chen, C.; Chai, Z.; Alsaedi, A.; Hayat, T.; Wang, X. Metal-organic framework-based materials: Superior adsorbents for the capture of toxic and radioactive metal ions. Chem. Soc. Rev. 2018, 47, 2322-2356. [CrossRef]

3. Yu, G.; Jiang, P.; Fu, X.; Liu, J.; Geoffrey, I.S.; Chen, Z.; He, X.; Lin, F.Y.; Wang, X.S. Phytoextraction of cadmium-contaminated soil by celosia Celosia argentea linn.: A long-term field study. Environ. Pollut. 2020, 115408. [CrossRef]

4. Sall, M.L.; Diaw, A.K.D.; Gningue-Sall, D. Toxic heavy metals: Impact on the environment and human health, and treatment with conducting organic polymers, a review. Environ. Sci. Pollut. Res. 2020, 27, 29927-29942. [CrossRef]

5. Liu, J.; Yu, G.; Jiang, P.; Zhang, X.F.; Meng, D.J.; Chen, Z.; Baker, A.J.M.; Qiu, R.L. Interaction of Mn and Cd during their uptake in Celosia argentea differs between hydroponic and soil systems. Plant Soil 2020, 450, 323-336. [CrossRef]

6. Vilardi, G.; Ochando-Pulido, J.; Verdone, N.; Stoller, M.; Palma, L. On the removal of hexavalent chromium by olive stones coated by iron-based nanoparticles: Equilibrium study and chromium recovery. J. Clean. Prod. 2018, 190, 200-210. [CrossRef]

7. Yu, G.; Liu, J.; Long, Y.; Chen, Z.; Sunahara, G.I.; Jiang, P.; You, S.Y.; Lin, H.; Xiao, H. Phytoextraction of cadmium-contaminated soils: Comparison of plant species and low molecular weight organic acids. Int. J. Phytoremediation 2019, 22, 383-391. [CrossRef]

8. Hou, S.; Wu, B.; Peng, D.; Wang, Z.; Wang, Y.; Xu, H. Remediation performance and mechanism of hexavalent chromium in alkaline soil using multi-layer loaded nano-zero-valent iron. Environ. Pollut. 2019, 252, 553-561. [CrossRef]

9. Nagajyoti, P.C.; Lee, K.D.; Tvm, S. Heavy metals, occurrence and toxicity for plants: A review. Environ. Chem. Lett. 2010, 8 , 199-216. [CrossRef]

10. Alidokht, L.; Khataee, A.R.; Reyhanitabar, A.; Oustan, S. Reductive removal of Cr(VI) by starch-stabilized Fe0 nanoparticles in aqueous solution. Desalination 2011, 270, 105-110. [CrossRef] 
11. Yu, X.Z.; Wang, D.Q.; Zhang, X.H. Chelator-induced phytoextraction of zinc and copper by rice seedlings. Ecotoxicology 2014, 23, 749-756. [CrossRef]

12. Zhai, T.; Fang, X.; Liao, M.; Xu, X.; Zeng, H.; Yoshio, B.; Golberg, D. A Comprehensive Review of One-Dimensional Metal-Oxide Nanostructure Photodetectors. Sensors 2009, 9, 6504-6529. [CrossRef]

13. Meunier, N.; Drogui, P.; Montane, C.; Hausler, R.; Mercier, G.; Blais, J.F. Comparison between electrocoagulation and chemical precipitation for metals removal from acidic soil leachate. J. Hazard. Mater. 2006, 137, 581-590. [CrossRef]

14. Minju, N.; Swaroop, K.; Haribabu, K.; Sivasubramanian, V.; Kumar, P. Removal of fluoride from aqueous media by magnesium oxide-coated nanoparticles. Desalin. Water Treat. 2015, 53, 2905-2914. [CrossRef]

15. Liu, J.; Shang, W.; Zhang, X.; Zhu, Y.; Yu, K. Mn accumulation and tolerance in Celosia argentea Linn.: A new Mnhyperaccumulating plant species. J. Hazard. Mater. 2014, 267, 136-141. [CrossRef]

16. Cai, C.; Zhao, M.; Yu, Z.; Rong, H.; Zhang, C. Utilization of nanomaterials for in-situ remediation of heavy metal (loid) contaminated sediments: A review. Sci. Total Environ. 2019, 662, 205-217. [CrossRef]

17. Yu, S.; Wang, X.; Pang, H.; Zhang, R.; Song, W.; Fu, D.; Hayat, T.; Wang, X. Boron nitride-based materials for the removal of pollutants from aqueous solutions: A review. Chem. Eng. J. 2018, 333, 343-360. [CrossRef]

18. Phenrat, T.; Saleh, N.; Sirk, K.; Kim, H.-J.; Tilton, R.D.; Lowry, G.V. Stabilization of aqueous nanoscale zerovalent iron dispersions by anionic polyelectrolytes: Adsorbed anionic polyelectrolyte layer properties and their effect on aggregation and sedimentation. J. Nanopart. Res. 2008, 10, 795-814. [CrossRef]

19. Zhang, Y.; Wang, L.; Zhang, N.; Zhou, Z. Adsorptive environmental applications of MXene nanomaterials: A review. RSC Adv. 2018, 8, 19895-19905. [CrossRef]

20. Hu, R.; Wang, X.; Dai, S.; Shao, D.; Hayat, T.; Alsaedi, A. Application of graphitic carbon nitride for the removal of $\mathrm{Pb}(\mathrm{II})$ and aniline from aqueous solutions. Chem. Eng. J. 2015, 260, 469-477. [CrossRef]

21. Ihsanullah, A.A.; Al-Amer, A.M.; Laoui, T.; Al-Marri, M.J.; Nasser, M.S.; Khraisheh, M.; Atieh, M.A. Heavy metal removal from aqueous solution by advanced carbon nanotubes: Critical review of adsorption applications. Sep. Purif. Technol. 2016, 157, 141-161. [CrossRef]

22. Thines, R.K.; Mubarak, N.M.; Nizamuddin, S.; Sahu, J.N.; Abdullah, E.C.; Ganesan, P. Application potential of carbon nanomaterials in water and wastewater treatment: A review. J. Taiwan Inst. Chem. Eng. 2017, 72, 116-133. [CrossRef]

23. Ibrahim, R.K.; Hayyan, M.; AlSaadi, M.A.; Hayyan, A.; Ibrahim, S. Environmental application of nanotechnology: Air, soil, and water. Environ. Sci. Pollut. Res. 2016, 23, 13754-13788. [CrossRef]

24. Qiao, Y.; Wu, J.; Xu, Y.; Fang, Z.; Zheng, L.; Cheng, W.; Tsang, E.P.; Fang, J.; Zhao, D. Remediation of cadmium in soil by biochar-supported iron phosphate nanoparticles. Ecol. Eng. 2017, 106, 515-522. [CrossRef]

25. Zou, Y.; Wang, X.; Khan, A.; Wang, P.; Liu, Y.H.; Alsaedi, A.; Hayat, T.; Wang, X. Environmental remediation and application of nanoscale zero-valent iron and its composites for the removal of heavy metal ions: A review. Environ. Sci. Technol. 2016, 50, 7290-7304. [CrossRef]

26. Chaithawiwat, K.; Vangnai, A.; McEvoy, J.M.; Pruess, B.; Krajangpan, S.; Khan, E. Impact of nanoscale zero valent iron on bacteria is growth phase dependent. Chemosphere 2016, 144, 352-359. [CrossRef] [PubMed]

27. Lefevre, E.; Bossa, N.; Wiesner, M.R.; Gunsch, C.K. A review of the environmental implications of in situ remediation by nanoscale zero valent iron (nZVI): Behavior, transport and impacts on microbial communities. Sci. Total Environ. 2016, 565, 889-901. [CrossRef]

28. Abbas, Q.; Yousaf, B.; Amina Ali, M.U.; Munir, M.A.M.; El-Naggar, A.; Rinklebe, J.; Naushad, M.; Naushad, M. Transformation pathways and fate of engineered nanoparticles (ENPs) in distinct interactive environmental compartments: A review. Environ. Int. 2020, 138, 105646. [CrossRef]

29. Bhowmick, S.; Chakraborty, S.; Mondal, P.; Renterghem, W.V.; Berghe, S.V.D.; Roman-Ross, G.; Chatterjee, D.; Iglesias, M. Montmorillonite-supported nanoscale zero-valent iron for removal of arsenic from aqueous solution: Kinetics and mechanism. Chem. Eng. J. 2014, 243, 14-23. [CrossRef]

30. Khin, M.M.; Nair, A.S.; Babu, V.J.; Murugan, R.; Ramakrishna, S. A review on nanomaterials for environmental remediation. Energy Environ. Sci. 2012, 5, 8075-8109. [CrossRef]

31. Jiang, Z.; Lv, L.; Zhang, W.; Du, Q.; Pan, B.; Yang, L.; Zhang, Q. Nitrate reduction using nanosized zero-valent iron supported by polystyrene resins: Role of surface functional groups. Water Res. 2011, 45, 2191-2198. [CrossRef]

32. Fu, R.; Yang, Y.; Xu, Z.; Zhang, X.; Guo, X.; Bi, D. The removal of chromium (VI) and lead (II) from groundwater using sepiolite-supported nanoscale zero-valent iron (S-NZVI). Chemosphere 2015, 138, 726-734. [CrossRef] [PubMed]

33. Liang, S.; Jin, Y.; Liu, W.; Li, X.; Shen, S.; Ding, L. Feasibility of Pb phytoextraction using nano-materials assisted ryegrass: Results of a one-year field-scale experiment. J. Environ. Manag. 2017, 190, 170-175. [CrossRef]

34. Tosco, T.; Papini, M.P.; Viggi, C.C.; Sethi, R. Nanoscale zerovalent iron particles for groundwater remediation: A review. J. Clean. Prod. 2014, 77, 10-21. [CrossRef]

35. Gu, P.; Zhang, S.; Li, X.; Wang, X.; Wen, T.; Jehan, R.; Alsaedi, A.; Hayat, T.; Wang, X. Recent advances in layered double hydroxide-based nanomaterials for the removal of radionuclides from aqueous solution. Environ. Pollut. 2018, 240, 493-505. [CrossRef] [PubMed]

36. Geary, S.M.; Morris, A.S.; Salem, A.K. Assessing the effect of engineered nanomaterials on the environment and human health. J. Allergy Clin. Immunol. 2016, 138, 405-408. [CrossRef] 
37. Liu, W.; Tian, S.; Zhao, X.; Xie, W.; Gong, Y.; Zhao, D. Application of stabilized nanoparticles for in situ remediation of metal-contaminated soil and groundwater: A critical review. Curr. Pollut. Rep. 2015, 1, 280-291. [CrossRef]

38. Stone, V.; Nowack, B.; Baun, A.; van den Brink, N.; Kammer, F.; Dusinska, M.; Handy, R.; Hankin, S.; Hassellov, M.; Joner, E.; et al. Nanomaterials for environmental studies: Classification, reference material issues, and strategies for physicochemical characterisation. Sci. Total Environ. 2010, 408, 1745-1754. [CrossRef]

39. Ren, X.M.; Chen, C.L.; Nagatsu, M.; Wang, X.K. Carbon nanotubes as adsorbents in environmental pollution management: A review. Chem. Eng. J. 2011, 170, 395-410. [CrossRef]

40. Fu, F.; Dionysiou, D.D.; Liu, H. The use of zero-valent iron for groundwater remediation and wastewater treatment: A review. J. Hazard. Mater. 2014, 267, 194-205. [CrossRef]

41. Yang, F.; Zhang, S.; Sun, Y.; Cheng, K.; Li, J.; Tsang, D.C.W. Fabrication and characterization of hydrophilic corn stalk biocharsupported nanoscale zero-valent iron composites for efficient metal removal. Bioresour. Technol. 2018, 265, 490-497. [CrossRef] [PubMed]

42. Boparai, H.K.; Meera Joseph, M.; O'Carroll, D.M. Kinetics and thermodynamics of cadmium ion removal by adsorption onto nano zerovalent iron particles. J. Hazard. Mater. 2011, 186, 458-465. [CrossRef] [PubMed]

43. Shang, J.; Zong, M.; Yu, Y.; Kong, X.; Du, Q.; Liao, Q. Removal of chromium (VI) from water using nanoscale zerovalent iron particles supported on herb-residue biochar. J. Environ. Manag. 2017, 197, 331-337. [CrossRef] [PubMed]

44. Su, H.; Fang, Z.; Tsang, P.E.; Fang, J.; Zhao, D. Stabilisation of nanoscale zero-valent iron with biochar for enhanced transport and in-situ remediation of hexavalent chromium in soil. Environ. Pollut. 2016, 214, 94-100. [CrossRef]

45. Zhang, D.; Gao, W.; Chang, G.; Luo, S.; Jiao, W.; Liu, Y. Removal of heavy metal lead(II) using nanoscale zero-valent iron with different preservation methods. Adv. Powder Technol. 2019, 30, 581-589. [CrossRef]

46. Cao, Y.; Zhang, S.; Zhong, Q.; Wang, G.; Xu, X.; Li, T.; Wang, L.; Jia, Y.; Li, Y. Feasibility of nanoscale zero-valent iron to enhance the removal efficiencies of heavy metals from polluted soils by organic acids. Ecotoxicol. Environ. Saf. 2018, 162, 464-473. [CrossRef]

47. Ahmed, A.M.; Ali, M.; Noor, A.H. Removal of zinc ions from aqueous solution by bioadsorbents and CNTs. Am. J. Mater. Sci. 2016, 6, 105-114. [CrossRef]

48. Alimohammady, M.; Jahangiri, M.; Kiani, F.; Tahermansouri, H. Design and evaluation of functionalized multi-walled carbon nanotubes by 3-aminopyrazole for the removal of $\mathrm{Hg}(\mathrm{II})$ and $\mathrm{As}(\mathrm{III})$ ions from aqueous solution. Res. Chem. Intermed. 2018, 44, 69-92. [CrossRef]

49. Lu, C.; Chiu, H. Adsorption of zinc(II) from water with purified carbon nanotubes. Chem. Eng. Sci. 2006, 61, 1138-1145. [CrossRef]

50. Mohammad, A.M.; Salah Eldin, T.A.; Hassan, M.A.; El-Anadouli, B.E. Efficient treatment of lead-containing wastewater by hydroxyapatite/chitosan nanostructures. Arab. J. Chem. 2017, 10, 683-690. [CrossRef]

51. Mironyuk, I.; Tatarchuk, T.; Naushad, M.; Vasylyeva, H.; Mykytyn, I. Highly efficient adsorption of strontium ions by carbonated mesoporous $\mathrm{TiO}_{2}$. J. Mol. Liq. 2019, 285, 742-753. [CrossRef]

52. Zand, A.D.; Tabrizi, A.M.; Heir, A.V. Application of titanium dioxide nanoparticles to promote phytoremediation of Cd-polluted soil: Contribution of PGPR inoculation. Bioremediat. J. 2020, 24, 171-189. [CrossRef]

53. Crane, R.; Scott, T. Nanoscale zero-valent iron: Future prospects for an emerging water treatment technology. J. Hazard. Mater. 2012, 211, 112-125. [CrossRef] [PubMed]

54. Elsner, M.; Chartrand, M.; VanStone, N.; Lacrampe Couloume, G.; Sherwood Lollar, B. Identifying abiotic chlorinated ethene degradation: Characteristic isotope patterns in reaction products with nanoscale zero-valent iron. Environ. Sci. Technol. 2008, 42, 5963-5970. [CrossRef]

55. Luo, S.; Lu, T.; Peng, L.; Shao, J.; Zeng, Q.; Gu, J. Synthesis of nanoscale zerovalent iron immobilized in alginate microcapsules for removal of $\mathrm{Pb}$ (II) from aqueous solution. J. Mater. Chem. 2014, 2, 15463-15472. [CrossRef]

56. Mueller, N.; Braun, J.; Bruns, J.; Cernik, M.; Rissing, P.; Rickerby, D.; Nowack, B. Application of nanoscale zero valent iron (NZVI) for groundwater remediation in Europe. Environ. Sci. Pollut. Res. 2012, 19, 550-558. [CrossRef]

57. Klimkova, S.; Cernik, M.; Lacinova, L.; Filip, J.; Jancik, D.; Zboril, R. Zero-valent iron nanoparticles in treatment of acid mine water from in situ uranium leaching. Chemosphere 2011, 82, 1178-1184. [CrossRef]

58. Huang, D.; Qin, X.; Peng, Z.; Liu, Y.; Gong, X.; Zeng, G.; Huang, C.; Cheng, M.; Xue, W.; Wang, X.; et al. Nanoscale zero-valent iron assisted phytoremediation of $\mathrm{Pb}$ in sediment: Impacts on metal accumulation and antioxidative system of Lolium perenne. Ecotoxicol. Environ. Saf. 2018, 153, 229-237. [CrossRef]

59. Vítková, M.; Puschenreite, M.; Komárek, M. Effect of nano zero-valent iron application on As, Cd, Pb, and Zn availability in the rhizosphere of metal(loid) contaminated soils. Chemosphere 2018, 200, 217-226. [CrossRef]

60. Han, W.; Fu, F.; Cheng, Z.; Wu, S. Studies on the optimum conditions using acid-washed zero-valent iron/aluminum mixtures in permeable reactive barriers for the removal of different heavy metal ions from wastewater. J. Hazard. Mater. 2016, 302, 437-446. [CrossRef]

61. Kang, S.; Pinault, M.; Pfefferle, L.D.; Elimelech, M. Single-walled carbon nanotubes exhibit strong antimicrobial activity. Langmuir 2007, 23, 8670-8673. [CrossRef] [PubMed]

62. Li, J.; Chen, C.; Zhang, S.; Wang, X. Surface functional groups and defects on carbon nanotubes affect adsorption-desorption hysteresis of metal cations and oxoanions in water. Environ. Sci. Nano 2014, 1, 488-495. [CrossRef]

63. Trojanowicz, M. Analytical applications of carbon nanotubes: A review. Trac-Trends Anal. Chem. 2006, 25, 480-489. [CrossRef] 
64. Lv, X.; Xu, J.; Jiang, G.; Xu, X. Removal of chromium (VI) from wastewater by nanoscale zero-valent iron particles supported on multiwalled carbon nanotubes. Chemosphere 2011, 85, 1204-1209. [CrossRef] [PubMed]

65. Helland, A.; Wick, P.; Koehler, A.; Schmid, K.; Som, C. Reviewing the environmental and human health knowledge base of carbon nanotubes. Environ. Health Perspect. 2007, 115, 1125-1131. [CrossRef]

66. Sheng, G.; Alsaedi, A.; Shammakh, W.; Monaquel, S.; Sheng, J.; Wang, X.; Li, H.; Huang, Y. Enhanced sequestration of selenite in water by nanoscale zero valent iron immobilization on carbon nanotubes by a combined batch, XPS and XAFS investigation. Carbon 2016, 99, 123-130. [CrossRef]

67. Mubarak, N.M.; Sahu, J.N.; Abdullah, E.C.; Jayakumar, N.S.; Ganesan, P. Microwave-assisted synthesis of multi-walled carbon nanotubes for enhanced removal of $\mathrm{Zn}$ (II) from wastewater. Res. Chem. Intermed. 2015, 42, 1-25. [CrossRef]

68. Sun, W.L.; Jiang, B.F.; Wang, F.; Xu, N. Effect of carbon nanotubes on Cd(II) adsorption by sediments. Chem. Eng. J. 2015, 264, 645-653. [CrossRef]

69. Osman, A.I.; Blewitt, J.; Abu-Dahrieh, J.K.; Farrell, C.; Ala'a, H.; Harrison, J.; Rooney, D.W. Production and characterisation of activated carbon and carbon nanotubes from potato peel waste and their application in heavy metal removal. Environ. Sci. Pollut. Res. 2019, 26, 37228-37241. [CrossRef]

70. Yaghmaeian, K.; Mashizi, R.K.; Nasseri, S.; Mahvi, A.H.; Ali-mohammadi, M.; Nazmara, S. Removal of inorganic mercury from aquatic environments by multi-walled carbon nanotubes. J. Environ. Health Sci. Eng. 2015, 13, 55. [CrossRef]

71. Sobhanardakani, S.; Zandipak, R.; Cheraghi, M. Adsorption of $\mathrm{Cu}^{2+}$ ions from aqueous solutions using oxidized multi-walled carbon nanotubes. Avicenna J. Environ. Health Eng. 2015, 2, e790. [CrossRef]

72. Xu, J.; Cao, Z.; Zhang, Y.; Yuan, Z.; Lou, Z.; Xu, X.; Wang, X. A review of functionalized carbon nanotubes and graphene for heavy metal adsorption from water: Preparation, application, and mechanism. Chemosphere 2018, 195, 351-364. [CrossRef]

73. Taghipour, S.; Hosseini, S.M.; Ataie-Ashtiani, B. Engineering nanomaterials for water and wastewater treatment: Review of classifications, properties and applications. New J. Chem. 2019, 43, 7902-7927. [CrossRef]

74. Dong, H.; Zeng, G.; Tang, L.; Fan, C.; Zhang, C.; He, X.; He, Y. An overview on limitations of TiO 2 -based particles for photocatalytic degradation of organic pollutants and the corresponding countermeasures. Water Res. 2015, 79, 128-146. [CrossRef] [PubMed]

75. Nguyen, V.N.H.; Amal, R.; Beydoun, D. Effect of formate and methanol on photoreduction/removal of toxic cadmium ions using $\mathrm{TiO}_{2}$ semiconductor as photocatalyst. Chem. Eng. Sci. 2003, 58, 4429-4439. [CrossRef]

76. Goutam, S.P.; Saxena, G.; Singh, V.; Yadav, A.K.; Bharagava, R.N.; Thapa, K.B. Green synthesis of $\mathrm{TiO}_{2}$ nanoparticles using leaf extract of Jatropha curcas L. For photocatalytic degradation of tannery wastewater. Chem. Eng. J. 2018, 336, 386-396. [CrossRef]

77. Mahmoud, M.E.; Ali, S.A.A.; Elweshahy, S.M. Microwave functionalization of titanium oxide nanoparticles with chitosan nanolayer for instantaneous microwave sorption of $\mathrm{Cu}$ (II) and Cd (II) from water. Int. J. Biol. Macromol. 2018, 111, 393-399. [CrossRef]

78. Gebru, K.A.; Das, C. Removal of $\mathrm{Pb}$ (II) and $\mathrm{Cu}$ (II) ions from wastewater using composite electrospun cellulose acetate/titanium oxide $\left(\mathrm{TiO}_{2}\right)$ adsorbent. J. Water Process Eng. 2017, 16, 1-13. [CrossRef]

79. Fan, X.; Wang, C.; Wang, P.; Hu, B.; Wang, X. TiO 2 nanoparticles in sediments: Effect on the bioavailability of heavy metals in the freshwater bivalve Corbicula fluminea. J. Hazard. Mater. 2018, 342, 41-50. [CrossRef]

80. Singh, J.; Lee, B.K. Influence of nano- $\mathrm{TiO}_{2}$ particles on the bioaccumulation of Cd in soybean plants (Glycine max): A possible mechanism for the removal of Cd from the contaminated soil. J. Environ. Manag. 2016, 170, 88-96. [CrossRef]

81. Zhao, Y.; Zhao, D.; Chen, C.; Wang, X. Enhanced photo-reduction and removal of Cr(VI) on reduced graphene oxide decorated with $\mathrm{TiO}_{2}$ nanoparticles. J. Colloid Interface Sci. 2013, 405, 211-217. [CrossRef] [PubMed]

82. Feng, Y.A.; Gong, J.L.; Zeng, G.M.; Niu, Q.Y.; Zhang, H.Y.; Niu, C.G.; Deng, J.H.; Yan, M. Adsorption of Cd (II) and Zn (II) from aqueous solutions using magnetic hydroxyapatite nanoparticles as adsorbents. Chem. Eng. J. 2010, 162, 487-494. [CrossRef]

83. Chen, J.; Qiu, X.; Fang, Z.; Yang, M.; Pokeung, T.; Gu, F.; Cheng, W.; Lan, B. Removal mechanism of antibiotic metronidazole from aquatic solutions by using nanoscale zero-valent iron particles. Chem. Eng. J. 2012, 181-182, 113-119. [CrossRef]

84. Zhao, X.; Liu, W.; Cai, Z.; Han, B.; Qian, T.; Zhao, D. An overview of preparation and applications of stabilized zero-valent iron nanoparticles for soil and groundwater remediation. Water Res. 2016, 100, 245-266. [CrossRef] [PubMed]

85. Liu, T.; Wang, Z.; Yan, X.; Zhang, B. Removal of mercury (II) and chromium (VI) from wastewater using a new and effective composite: Pumice-supported nanoscale zero-valent iron. Chem. Eng. J. 2014, 245, 34-40. [CrossRef]

86. Wu, J.; Wang, X.B.; Zeng, R.J. Reactivity enhancement of iron sulfide nanoparticles stabilized by sodium alginate: Taking Cr (VI) removal as an example. J. Hazard. Mater. 2017, 333, 275-284. [CrossRef]

87. Xu, Y.; Zhao, D. Reductive immobilization of chromate in water and soil using stabilized iron nanoparticles. Water Res. 2007, 41, 2101-2108. [CrossRef]

88. Wu, Y.; Pang, H.; Liu, Y.; Wang, X.; Yu, S.; Fu, D.; Chen, J.; Wang, X. Environmental remediation of heavy metal ions by novel-nanomaterials: A review. Environ. Pollut. 2019, 246, 608-620. [CrossRef]

89. Kumar, P.; Sivaranjanee, R.; Rajan, P.; Saravanan, A. Carbon sphere: Synthesis, characterization and elimination of toxic Cr(VI) ions from aquatic system. J. Ind. Eng. Chem. 2018, 60, 307-320. [CrossRef]

90. Gong, Y.; Liu, Y.; Xiong, Z.; Zhao, D. Immobilization of mercury by carboxymethyl cellulose stabilized iron sulfide nanoparticles: Reaction mechanisms and effects of stabilizer and water chemistry. Environ. Sci. Technol. 2014, 48, 3986-3994. [CrossRef]

91. Lv, X.; Xu, J.; Jiang, G.; Tang, J.; Xu, X. Highly active nanoscale zero-valent iron (nZVI)-Fe $\mathrm{O}_{4}$ nanocomposites for the removal of chromium(VI) from aqueous solutions. J. Colloid Interface Sci. 2012, 369, 460-469. [CrossRef] [PubMed] 
92. Arshadi, M.; Soleymanzadeh, M.; Salvacion, J.W.L.; SalimiVahid, F. Nanoscale zero-valent iron(NZVI) supported on sineguelas waste for $\mathrm{Pb}(\mathrm{II})$ removal from aqueous solution: Kinetics, thermodynamic and mechanism. J. Colloid Interface Sci. 2014, 426, 241-251. [CrossRef] [PubMed]

93. Dubey, R.; Bajpai, J.; Bajpai, A.K. Chitosan-alginate nanoparticles (CANPs) as potential nanosorbent for removal of $\mathrm{Hg}$ (II) ions. Environ. Nanotech. Monit. Manag. 2016, 6, 32-44. [CrossRef]

94. Zhang, Y.N.; Zhang, Y.J.; Akakuru, O.U.; Xu, X.; Wu, A. Research progress and mechanism of nanomaterials-mediated in-situ remediation of cadmium-contaminated soil: A. critical review. J. Environ. Sci. 2020, 104, 351-364. [CrossRef]

95. Nassar, N.N. Rapid removal and recovery of $\mathrm{Pb}(\mathrm{II})$ from wastewater by magnetic nanoadsorbents. J. Hazard. Mater. 2010, 184, 538-546. [CrossRef] [PubMed]

96. Vilardi, G.; Mpouras, T.; Dermatas, D.; Verdone, N.; Polydera, A.; Palma, L. Nanomaterials application for heavy metals recovery from polluted water: The combination of nano zero-valent iron and carbon nanotubes. Competitive adsorption non-linear modeling. Chemosphere 2018, 201, 716-729. [CrossRef] [PubMed]

97. Karn, B.; Kuiken, T.; Otto, M. Nanotechnology and in situ remediation: A review of the benefits and potential risks. Environ. Health Perspect. 2009, 117, 1823-1831. [CrossRef]

98. Hristozov, D.; Malsch, I.; Hristozov, D.; Malsch, I. Hazards and risks of engineered nanoparticles for the environment and human health. Sustainability 2009, 1, 1161-1194. [CrossRef]

99. Lamine, S.; Petropoulos, G.P.; Brewer, P.A.; Bachari, N.-E.-I.; Srivastava, P.K.; Manevski, K.; Kalaitzidis, C.; Macklin, M.G. Heavy Metal Soil Contamination Detection Using Combined Geochemistry and Field Spectroradiometry in the United Kingdom. Sensors 2019, 19, 762. [CrossRef]

100. Ye, C.; Li, S.Y.; Zhang, Y.L.; Zhang, Q.F. Assessing soil heavy metal pollution in the water-level-fluctuation zone of the Three Gorges Reservoir, China. J. Hazard. Mater. 2011, 191, 366-372. [CrossRef]

101. Seleiman, M.F.; Almutairi, K.F.; Alotaibi, M.; Shami, A.; Alhammad, B.A.; Battaglia, M.L. Nano-Fertilization as an Emerging Fertilization Technique: Why Can Modern Agriculture Benefit from Its Use? Plants 2021, 10, 2. [CrossRef] [PubMed]

102. Seleiman, M.F.; Alotaibi, M.A.; Alhammad, B.A.; Alharbi, B.M.; Refay, Y.; Badawy, S.A. Effects of ZnO Nanoparticles and Biochar of Rice Straw and Cow Manure on Characteristics of Contaminated Soil and Sunflower Productivity, Oil Quality, and Heavy Metals Uptake. Agronomy 2020, 10, 790. [CrossRef]

103. Seleiman, M.F.; Ali, S.; Refay, Y.; Alhammad, B.A.; El-Hendawy, S.E. Chromium resistant microbes and melatonin reduced Cr uptake and toxicity, improved physio-biochemical traits and yield of wheat in contaminated soil. Chemosphere 2020, 250, 126239. [CrossRef] [PubMed]

104. Sajid, M. Toxicity of nanoscale metal organic frameworks: A perspective. Environ. Sci. Pollut. Res. 2016, 23, 14805-14807. [CrossRef] [PubMed]

105. Chen, J.; Xiu, Z.; Lowry, G.; Alvarez, P. Effect of natural organic matter on toxicity and reactivity of nano-scale zero-valent. Water Res. 2011, 45, 1995-2001. [CrossRef] [PubMed]

106. Lu, J.; Tian, S.; Lv, X.; Chen, Z.; Chen, B.; Zhu, X.; Cai, Z. $\mathrm{TiO}_{2}$ nanoparticles in the marine environment: Impact on the toxicity of phenanthrene and $\mathrm{Cd}^{+}$to marine zooplankton Artemia salina. Sci. Total Environ. 2018, 615, 375-380. [CrossRef]

107. Deng, X.Y.; Cheng, J.; Hu, X.L.; Wang, L.; Li, D.; Gao, K. Biological effects of $\mathrm{TiO}_{2}$ and $\mathrm{CeO}_{2}$ nanoparticles on the growth, photosynthetic activity, and cellular components of a marine diatom Phaeodactylum tricornutum. Sci. Total Environ. 2017, 575, 87-96. [CrossRef]

108. Lam, C.W.; James, J.T.; McCluskey, R. Pulmonary toxicity of single-wall carbon nanotubes in mice 7 and 90 days after intratracheal instillation. Toxicol. Sci. 2004, 77, 126-134. [CrossRef]

109. Lindberg, H.K.; Falck, G.C.-M.; Suhonen, S.; Vippola, M.; Vanhala, E.; Catalán, J. Genotoxicity of nanomaterials: DNA damage and micronuclei induced by carbon nanotubes and graphite nanofibres in human bronchial epithelial cells in vitro. Toxicol. Lett. 2009, 186, 166-173. [CrossRef]

110. Kadar, E.; Dyson, O.; Handy, R.D.; Al-Subiai, S.N. Are reproduction impairments of free spawning marine invertebrates exposed to zero-valent nano-iron associated with dissolution of nanoparticles? Nanotoxicology 2013, 7, 135-143. [CrossRef] [PubMed]

111. El-Temsah, Y.S.; Joner, E.J. Effects of nano-sized zero-valent iron (nZVI) on DDT degradation in soil and its toxicity to collembola and ostracods. Chemosphere 2013, 92, 131-137. [CrossRef] [PubMed]

112. Fajardo, C.; Ortíz, L.T.; Rodríguez-Membibre, M.L.; Nande, M.; Lobo, M.C.; Martin, M. Assessing the impact of zero-valent iron (ZVI) nanotechnology on soil microbial structure and functionality: A molecular approach. Chemosphere 2012, 86, 802-808. [CrossRef] [PubMed]

113. Louie, S.M.; Tilton, R.D.; Lowry, G.V. Critical review: Impacts of macromolecular coatings on critical physicochemical processes controlling environmental fate of nanomaterials. Environ. Sci. Nano 2016, 3, 283-310. [CrossRef] 